\title{
The Bruton tyrosine kinase inhibitor ibrutinib improves anti-MAG antibody polyneuropathy
}

Francesca Castellani, MD, * Andrea Visentin, MD, PhD, * Marta Campagnolo, MD, Alessandro Salvalaggio, MD, Mario Cacciavillani, MD, PhD, Cinzia Candiotto, PhD, Roberta Bertorelle, MD, Livio Trentin, MD, and

Chiara Briani, MD

\section{Abstract}

\section{Objective}

To assess whether neuropathy with anti-myelin-associated glycoprotein (MAG) antibody may improve after treatment with ibrutinib, an oral inhibitor of Bruton tyrosine kinase, we prospectively treated with ibrutinib a cohort of 3 patients with anti-MAG neuropathy and Waldenström macroglobulinemia (WM).

\section{Methods}

All 3 patients underwent bone marrow biopsy showing WM, with MYD88 ${ }^{L 265 P}$ mutated and CXCR4 ${ }^{\text {S338X }}$ wild type, and were started on ibrutinib $420 \mathrm{mg} /$ die. Patients were assessed at baseline, at 3-6-9 months, and at 12 months in 2 patients with a longer follow-up, using Inflammatory Neuropathy Cause and Treatment (INCAT) Disability Score, INCAT sensory sum score, and Medical Research Council sum score. The modified International Cooperative Ataxia Rating Scale was performed in 2 patients, whereas it was not used in the patient with Parkinson disease as a major comorbidity. Responders were considered the patients improving by at least one point in 2 clinical scales.

\section{Results}

All the patients reported an early and subjective benefit, consistent with the objective improvement, especially of the sensory symptoms as shown by clinical scales. Treatment was well tolerated.

\section{Conclusion}

These preliminary data point to a possible efficacy of ibrutinib in anti-MAG antibody neuropathy, which is the most common disabling paraproteinemic neuropathy, where active treatment is eagerly needed.

\section{Classification of evidence}

This study provides Class IV evidence that for patients with anti-MAG antibody neuropathy, ibrutinib improves neuropathy symptoms.
Correspondence

Dr. Briani

chiara.briani@unipd.it

\section{MORE ONLINE}

$\rightarrow$ Class of Evidence

Criteria for rating

therapeutic and diagnostic

studies

NPub.org/coe 


\section{Glossary}

BMB = bone marrow biopsy; BTK = Bruton tyrosine kinase; IgM = immunoglobulin M; INCAT = Inflammatory Neuropathy Cause and Treatment; MAG = myelin-associated glycoprotein; MGUS = monoclonal gammopathy of undetermined significance; $\mathbf{W M}=$ Waldenström macroglobulinemia.

Anti-myelin-associated glycoprotein (MAG) antibody neuropathy is a chronic sensorimotor demyelinating polyneuropathy associated with immunoglobulin M (IgM) monoclonal gammopathy, manifestation of either a monoclonal gammopathy of undetermined significance (MGUS) or of a non-Hodgkin lymphoma, such as Waldenström macroglobulinemia (WM). ${ }^{1,2}$ Anti-MAG antibodies are pathogenic, ${ }^{3}$ and rituximab, a chimeric anti-CD20 monoclonal antibody, is currently the standard treatment. However, rituximab provides benefit in less than $50 \%$ of patients, ${ }^{4}$ and repeated cycles are often necessary with progressive loss of benefit.

Recently, the discovery of the mutational profile of the MYD88 and CXCR4 genes has radically changed the diagnostic and prognostic evaluation of IgM monoclonal gammopathies. MYD88 ${ }^{\mathrm{L} 265 \mathrm{P}}$ has been found to be the most common mutation in WM and IgM-MGUS, ${ }^{5}$ conferring prosurvival stimuli to tumor cells through constitutive activation of the Bruton tyrosine kinase (BTK) and nuclear factor kappa-light-chain-enhancer of activated $\mathrm{B}$ cells signaling. Conversely, the less common CXCR4 mutations are associated with adverse prognosis. Ibrutinib, the first-in-class inhibitor of BTK, has already been shown to be efficacious in B-cell non-Hodgkin lymphomas including WM, especially in those harboring MYD88 ${ }^{\mathrm{L} 265 \mathrm{P}}$ mutation and CXCR4 gene wild-type.,

In the study by Treon et al., 59 of 63 patients, 3 of whom had anti-MAG antibodies, received ibrutinib for progressive neuropathy. Subjective improvement occurred in 5 patients and 4 remained stable. In a subsequent study, ${ }^{6} 4$ of 31 patients with WM had been treated with ibrutinib for neuropathy, 2 remained stable and 2 had subjective improvement starting from week 9, with subsequent complete recovery in one patient. Despite the possibility of hematologic evaluation might have lacked specific scales to grade the response of neuropathy, still these preliminary data are promising and show that ibrutinib does not worsen rather may improve neuropathy.

We report on 3 patients with anti-MAG antibody neuropathy who had been successfully treated with ibrutinib. Demographic and hematologic data are summarized in table 1 . All patients had neurophysiologic evidence of sensory-motor demyelinating polyneuropathy, with secondary axonal damage involving distal motor fibers in one patient (1).

The patients were assessed with Inflammatory Neuropathy Cause and Treatment (INCAT) Disability Score, ${ }^{7}$ INCAT sensory sum score, ${ }^{8}$ and Medical Research Council sum score. The modified International Cooperative Ataxia Rating Scale ${ }^{9}$ was also performed in 2 patients ( 1 and 3 ) to evaluate tremor and gait, whereas it was not used in patient 2 , who had Parkinson disease as a major comorbidity. Responders were considered those patients who improved by at least one point in 2 clinical scales. Data regarding clinical scales are summarized in table 2.

Patient 1 is a 73-year-old man, with a long history (from 2008) of anti-MAG antibody neuropathy. He had undergone therapy with plasma exchange, IV immunoglobulins, and rituximab with only partial benefit. After worsening, in December 2018, bone marrow biopsy (BMB) showed WM, with MYD $88^{\mathrm{L} 265 \mathrm{P}}$ mutation and a lack of CXCR4 ${ }^{\mathrm{S} 338 \mathrm{X}}$. Ibrutinib $420 \mathrm{mg} /$ die was started in January 2019. At baseline, he presented with distal weakness and hypoesthesia at the lower limbs, loss of vibration sense up to the knee, lower limbs areflexia, and upper limbs tremor (table 2). After 1 and 3 months of treatment, there was a slight improvement in touch sensation at the feet and in motor deficit at the toes (table 2). After 6 months, further improvement in touch sensation and distal motor deficit occurred, whereas tremor persisted. The clinical benefit was stable at 12 months (table 2). Monoclonal protein and IgM levels decreased. Anti-MAG antibodies decreased at 3 months but gradually increased thereafter (table 1).

Patient 2 is a 80 -year-old man, affected with anti-MAG antibody neuropathy and Parkinson disease. BMB showed WM harboring MYD88 ${ }^{\mathrm{L} 265 \mathrm{P}}$ and unmutated CXCR4 gene. He started ibrutinib $420 \mathrm{mg} /$ die in February 2019. At baseline, there was a severe sensory-motor impairment at 4 limbs (distal lower limbs and grip strength deficit, hypoesthesia and loss of vibration sense up to the knee, lower limbs areflexia, postural tremor at upper limbs, table 2). After 1 and 3 months of treatment, a slight improvement in sensory signs and symptoms occurred, with vibration sense and reflexes reappearing at the knees (table 2). The improvement was maintained 12 months later. Monoclonal protein and IgM levels steadily decreased, whereas the antibody titers decreased at 3 months and then increased thereafter (table 1).

Patient 3 is a 74-year-old woman with WM and anti-MAG neuropathy since 2015. She was treated in 2016 with cyclophosphamide and rituximab, with clinical stability. In 2018, for progressive worsening of gait instability (frequent falls) and lower limbs dysesthesias (table 2), she underwent BMB that confirmed WM with MYD8 $8^{\mathrm{L} 265 \mathrm{P}}$ mutation and unmutated CXCR4 gene. The patient started ibrutinib $420 \mathrm{mg} /$ die in May 2019, and at the 1- and 3-month follow-ups, she already reported subjective improvement of touch sensation at the lower limbs (table 2). At the 6-month evaluation, she reported dramatic improvement in gait stability that further 


\begin{tabular}{|c|c|c|c|c|c|c|c|c|c|c|c|c|c|c|}
\hline & \multicolumn{5}{|c|}{$\# 1$ (IgM/K) } & \multicolumn{5}{|c|}{ 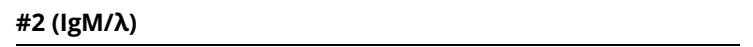 } & \multicolumn{4}{|c|}{ \#3 (IgM/к) } \\
\hline & 0 & +3 mo & $+6 \mathrm{mo}$ & +9 mo & $+12 \mathrm{mo}$ & 0 & +3 mo & $+6 \mathrm{mo}$ & +9 mo & $+12 \mathrm{mo}$ & 0 & +3 mo & $+6 \mathrm{mo}$ & $+9 \mathrm{mo}$ \\
\hline Age (y) & \multicolumn{5}{|l|}{73} & \multicolumn{5}{|l|}{81} & \multicolumn{4}{|l|}{74} \\
\hline eGFR ( $\mathrm{mL} / \mathrm{min})$ & \multicolumn{5}{|l|}{87} & \multicolumn{5}{|l|}{90} & \multicolumn{4}{|l|}{52} \\
\hline IPSSWM & \multicolumn{5}{|c|}{1 intermediate risk } & \multicolumn{5}{|c|}{2 intermediate risk } & \multicolumn{4}{|c|}{1 intermediate risk } \\
\hline Bone marrow LPL & \multicolumn{5}{|l|}{$10 \%$} & \multicolumn{5}{|l|}{$15 \%$} & \multicolumn{4}{|l|}{$15 \%$} \\
\hline MYD88 L265P & \multicolumn{5}{|c|}{ Mutated } & \multicolumn{5}{|c|}{ Mutated } & \multicolumn{4}{|c|}{ Mutated } \\
\hline CXCR4 S338X & \multicolumn{5}{|c|}{ Wild type } & \multicolumn{5}{|c|}{ Wild type } & \multicolumn{4}{|c|}{ Wild type } \\
\hline WBC (n/L) & 8.4 & 8.7 & 8.7 & 7.9 & 7.9 & 4.4 & 5.7 & 5.6 & 5.3 & 5.6 & 6.7 & 7.1 & 7.1 & 8.6 \\
\hline Lymph. (n/ $\mu \mathrm{L})$ & 3.2 & 3.1 & 2.6 & 2.3 & 2.4 & 1.1 & 1.0 & 1.7 & 0.9 & 0.5 & 1.4 & 1.8 & 1.6 & 1.78 \\
\hline $\mathrm{Hb}(\mathrm{g} / \mathrm{L})$ & 163 & 161 & 175 & 160 & 159 & 100 & 93 & 89 & 110 & 90 & 141 & 136 & 139 & 142 \\
\hline PLT (n/L) & 214 & 168 & 193 & 198 & 210 & 124 & 77 & 99 & 112 & 168 & 240 & 216 & 200 & 203 \\
\hline Paraprotein (g/L) & 6.5 & 5.0 & 5.4 & 4.0 & 4.28 & 7.2 & 3.5 & 3.3 & 3.4 & 3.7 & 10.6 & 5.9 & 5.6 & 5.4 \\
\hline IgM (g/L) & 7.2 & 3.5 & 4.3 & 3.6 & 3.5 & 13.7 & 5.2 & 6.6 & 6.3 & 6.4 & 15.9 & 10.2 & 8.8 & 8.3 \\
\hline FLC K (mg/L) & 69.8 & 59.2 & 57.2 & 46.6 & 40.3 & 15.3 & 24.5 & 20.6 & 23.0 & 37.7 & 35.3 & 29.6 & 27.5 & 27.8 \\
\hline FLC $\lambda(m g / L)$ & 18.3 & 14.3 & 13.5 & 15.1 & 15.0 & 28.9 & 22.7 & 18.9 & 22.5 & 27.0 & 14.2 & 11.2 & 11.8 & 13 \\
\hline Anti-MAG (BTU/L) & 52.9 & 35.1 & 67.9 & 60.4 & 51.7 & $>70.0$ & 50.6 & $>70.0$ & 70.0 & 64.6 & 51.5 & 37.8 & $>70.0$ & $>70.0$ \\
\hline B. J. protein & Neg & Neg & Neg & Neg & Neg & Neg & Neg & Neg & Neg & Neg & Neg & Neg & Neg & Neg \\
\hline
\end{tabular}

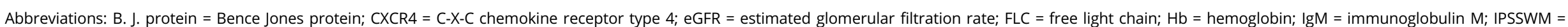

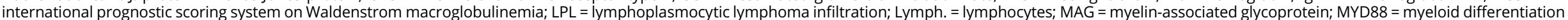
primary response 88; neg = negative; $\mathrm{PLT}=$ platelets; $\mathrm{WBC}=$ white blood cell count. 
Table 2 Clinical scales at the baseline and the follow-up of ibrutinib-treated patients

\begin{tabular}{|c|c|c|c|c|}
\hline & $\begin{array}{l}\text { INCAT } \\
\text { disability score } \\
\text { (upper limbs + } \\
\text { lower limbs) }\end{array}$ & ISS & $\begin{array}{l}\text { MRC sum } \\
\text { score }\end{array}$ & mICARS \\
\hline \multicolumn{5}{|l|}{1} \\
\hline Baseline & $2+2$ & 8 & 53 & 27 \\
\hline $3 \mathrm{mo}$ & $2+2$ & 6 & 55 & 27 \\
\hline $6 \mathrm{mo}$ & $2+1$ & 5 & 55 & 25 \\
\hline $9 \mathrm{mo}$ & $2+1$ & 5 & 55 & 25 \\
\hline $12 \mathrm{mo}$ & $2+1$ & 5 & 55 & 23 \\
\hline \multicolumn{5}{|c|}{2} \\
\hline Baseline & $4+4$ & 9 & 51 & - \\
\hline $3 \mathrm{mo}$ & $3+3$ & 6 & 53 & - \\
\hline $6 \mathrm{mo}$ & $3+3$ & 6 & 53 & - \\
\hline $9 \mathrm{mo}$ & $3+3$ & 6 & 53 & - \\
\hline $12 \mathrm{mo}$ & $3+3$ & 6 & 53 & - \\
\hline \multicolumn{5}{|c|}{3} \\
\hline Baseline & $0+1$ & 5 & 60 & 15 \\
\hline $3 \mathrm{mo}$ & $0+1$ & 4 & 60 & 15 \\
\hline $6 \mathrm{mo}$ & $0+1$ & 3 & 60 & 13 \\
\hline $9 \mathrm{mo}$ & $0+0$ & 3 & 60 & 10 \\
\hline
\end{tabular}

Abbreviations: INCAT = Inflammatory Neuropathy Cause and Treatment Disability Score; ISS = INCAT sensory sum score; MRC = Medical Research Council sum score; mICARS = modified International Cooperative Ataxia Rating Scale.

improved at month 9 (table 2). Monoclonal protein and IgM levels steadily decreased, whereas the antibody titers decreased at 3 months and then increased thereafter (table 1).

Therapy was well tolerated, and none developed atrial fibrillation or infections. All patients are currently still receiving treatment.

\section{Discussion}

Anti-MAG antibody neuropathy is a slowly progressive neuropathy that may become disabling when sensory ataxia worsens or motor impairment occurs. Efficacy after treatment with rituximab is reported only in approximately half of the patients, highlighting the unmet need for effective therapeutic options. The discovery of the mutational profile of the MYD 88 and CXCR4 genes ${ }^{10}$ have opened new potential therapeutic avenues. Data from previous hematologic studies ${ }^{5,6}$ were also encouraging regarding neuropathies, including those associated with anti-MAG antibodies.

We have reported on the first 3 patients treated with ibrutinib, 2 after the loss of response to rituximab. All the patients reported an early and subjective benefit, especially of the sensory symptoms, which has also been supported by the objective improvement of at least one point in 2 neurologic scales. Less perception of benefit after therapy was reported by the oldest patient, who had a concomitant disabling Parkinson disease. To note, an early improvement was also recorded in patient 1 , who had a long history of anti-MAG antibody neuropathy with poor response to previous treatments. The biological effect of ibrutinib was demonstrated by the steady decrease of the IgM levels and of the monoclonal component. Surprisingly (but consistently), the anti-MAG antibody titer decreased at the 3 months follow-up but at subsequent evaluation, increased regardless of the IgM level and of clinical improvement.

It is well known that the severity of the neuropathy does not correlate with the anti-MAG antibody titer, which also does not correlate with the paraprotein entity. Furthermore, if despite the halving of the monoclonal paraprotein, the antibody titer persists elevating, it is likely that the quantity of the antibody-producing cells is low compared with the whole paraprotein. Another possibility is that ibrutinib may succeed in eliminating the WM malignant cells, but it is less active in the lymphoplasmocytes producing anti-MAG antibodies. The possibility of serum factors that influence the in vitro antibody binding or the assays' variability because of the differences in the ELISA plates or their handling, or standard curves generated by positive controls, should also be considered. Finally, the lymphoplasmocytes that produce the anti-MAG antibodies may have a survival advantage, explaining why only less than $50 \%$ of anti-MAG neuropathy patients respond to rituximab or eventually relapse.

Our preliminary data in 3 patients point to a possible efficacy of ibrutinib in anti-MAG antibody neuropathy, which is the most common disabling paraproteinemic neuropathy.

\section{Study funding}

A. Visentin received a research fellowship from RCVRicerca per Credere nella Vita.

\section{Disclosure}

F. Castellani, A. Visentin, M. Campagnolo, A. Salvalaggio, M. Cacciavillani, C. Candiotto, and R. Bertorelle report no disclosures. L. Trentin received research founding by Janssen. C. Briani reports no disclosures. Go to Neurology.org/NN for full disclosures.

\section{Publication history}

Received by Neurology: Neuroimmunology \& Neuroinflammation December 23, 2019. Accepted in final form March 12, 2020.

\section{Appendix Authors}

\begin{tabular}{lll}
\hline Name & Location & Contribution \\
\hline $\begin{array}{ll}\text { Francesca } \\
\text { Castellani, MD }\end{array}$ & $\begin{array}{l}\text { Department of } \\
\text { Neurosciences, } \\
\text { University of Padova }\end{array}$ & $\begin{array}{l}\text { Major role in the acquisition } \\
\text { of data; analyzed the data; } \\
\text { interpreted the data; } \\
\text { drafted the manuscript for } \\
\text { intellectual content }\end{array}$ \\
\end{tabular}


Appendix (continued)

\begin{tabular}{|c|c|c|}
\hline Name & Location & Contribution \\
\hline $\begin{array}{l}\text { Andrea } \\
\text { Visentin, MD, } \\
\text { PhD }\end{array}$ & $\begin{array}{l}\text { Hematology and Clinical } \\
\text { Immunology Unit, } \\
\text { Department of Medicine, } \\
\text { University of Padova }\end{array}$ & $\begin{array}{l}\text { Major role in } \\
\text { the acquisition of } \\
\text { data; interpreted the } \\
\text { data; drafted the } \\
\text { manuscript for } \\
\text { intellectual content }\end{array}$ \\
\hline $\begin{array}{l}\text { Marta } \\
\text { Campagnolo, } \\
\text { MD }\end{array}$ & $\begin{array}{l}\text { Department of } \\
\text { Neurosciences, } \\
\text { University of Padova }\end{array}$ & $\begin{array}{l}\text { Major role in } \\
\text { the acquisition of } \\
\text { data; interpreted the } \\
\text { data }\end{array}$ \\
\hline $\begin{array}{l}\text { Alessandro } \\
\text { Salvalaggio, } \\
\text { MD }\end{array}$ & $\begin{array}{l}\text { Department of } \\
\text { Neurosciences, } \\
\text { University of Padova }\end{array}$ & $\begin{array}{l}\text { Major role in } \\
\text { the acquisition of } \\
\text { data; interpreted the } \\
\text { data }\end{array}$ \\
\hline $\begin{array}{l}\text { Mario } \\
\text { Cacciavillani, } \\
\text { MD, PhD }\end{array}$ & $\begin{array}{l}\text { CEMES, Data Medica } \\
\text { Group, Padova }\end{array}$ & $\begin{array}{l}\text { Major role in } \\
\text { the acquisition of } \\
\text { data; interpreted the } \\
\text { data }\end{array}$ \\
\hline $\begin{array}{l}\text { Cinzia } \\
\text { Candiotto, } \\
\text { PhD }\end{array}$ & $\begin{array}{l}\text { Immunology and } \\
\text { Molecular Oncology, } \\
\text { Veneto Institute of } \\
\text { Oncology IOV, IRCCS }\end{array}$ & $\begin{array}{l}\text { Major role in the } \\
\text { acquisition of the genetic } \\
\text { data; interpreted the data }\end{array}$ \\
\hline $\begin{array}{l}\text { Roberta } \\
\text { Bertorelle, MD }\end{array}$ & $\begin{array}{l}\text { Immunology and } \\
\text { Molecular Oncology, } \\
\text { Veneto Institute of } \\
\text { Oncology IOV, IRCCS }\end{array}$ & $\begin{array}{l}\text { Major role in the } \\
\text { acquisition of the genetic } \\
\text { data; interpreted the data }\end{array}$ \\
\hline $\begin{array}{l}\text { Livio Trentin, } \\
\text { MD }\end{array}$ & $\begin{array}{l}\text { Hematology and Clinical } \\
\text { Immunology Unit, } \\
\text { Department of Medicine, } \\
\text { University of Padova }\end{array}$ & $\begin{array}{l}\text { Major role in the } \\
\text { acquisition of data; } \\
\text { interpreted the data }\end{array}$ \\
\hline
\end{tabular}

Appendix (continued)

\begin{tabular}{lll}
\hline Name & Location & Contribution \\
\hline Chiara Briani, & $\begin{array}{l}\text { Department of } \\
\text { Meurosciences, } \\
\text { University of Padova }\end{array}$ & $\begin{array}{l}\text { Designed and } \\
\text { conceptualized the study; } \\
\text { coordinated the study; } \\
\text { interpreted the data; } \\
\text { drafted the manuscript for } \\
\text { intellectual content }\end{array}$ \\
&
\end{tabular}

\section{References}

1. Latov N, Sherman WH, Nemni R, et al. Plasma-cell dyscrasia and peripheral neuropathy with a monoclonal antibody to peripheral-nerve myelin. N Engl J Med 1980;303:618-621.

2. Briani C, Visentin A, Campagnolo $M$, et al. Peripheral nervous system involvement in lymphomas. J Peripher Nerv Syst 2019;24:5-18.

3. Dalakas MC. Advances in the diagnosis, immunopathogenesis and therapies of IgM-anti-MAG antibody-mediated neuropathies. Ther Adv Neurol Disord 2018;11: 1756285617746640

4. Lunn MP, Nobile-Orazio E. Immunotherapy for IgM anti-myelin-associated glycoprotein paraprotein-associated peripheral neuropathies. Cochrane Database Syst Rev 2016;10:CD002827.

5. Treon SP, Tripsas CK, Meid K, et al. Ibrutinib in previously treated Waldenström's macroglobulinemia. N Engl J Med 2015;372:1430-1440.

6. Dimopoulos MA, Trotman J, Tedeschi A, et al. Ibrutinib for patients with rituximabrefractory Waldenström's macroglobulinaemia (iNNOVATE): an open-label substudy of an international, multicentre, phase 3 trial. Lancet Oncol 2017;18:241-250.

7. Hughes R, Bensa S, Willison $\mathrm{H}$, et al; Inflammatory Neuropathy Cause and Treatment (INCAT) Group. Randomized controlled trial of intravenous immunoglobulin versus oral prednisolone in chronic inflammatory demyelinating polyradiculoneuropathy. Ann Neurol 2001;50:195-201.

8. Merkies IS, Schmitz PI, van der Mechè FG, van Doorn PA. Psychometric evaluation of a new sensory scale in immune-mediated polyneuropathies. Inflammatory Neuropathy Cause and Treatment (INCAT) Group. Neurology 2000;54:943-949.

9. Schmahmann JD, Gardner R, MacMore J, Vangel MG. Development of a brief ataxia rating scale (BARS) based on a modified form of the ICARS. Mov Disord 2009;24:1820-1828.

10. Vos JM, Notermans NC, D'Sa S, et al. High prevalence of the MYD88 L265P mutation in IgM anti-MAG paraprotein-associated peripheral neuropathy. J Neurol Neurosurg Psychiatry 2018;89:1007-1009. 


\section{Neurology \\ Neuroimmunology \& Neuroinflammation}

\section{The Bruton tyrosine kinase inhibitor ibrutinib improves anti-MAG antibody polyneuropathy}

Francesca Castellani, Andrea Visentin, Marta Campagnolo, et al.

Neurol Neuroimmunol Neuroinflamm 2020;7;

DOI 10.1212/NXI.0000000000000720

This information is current as of April 13, 2020

\section{Updated Information \& Services}

References

Citations

Subspecialty Collections

Permissions \& Licensing

Reprints including high resolution figures, can be found at:

http://nn.neurology.org/content/7/4/e720.full.html

This article cites 10 articles, 1 of which you can access for free at: http://nn.neurology.org/content/7/4/e720.full.html\#\#ref-list-1

This article has been cited by 3 HighWire-hosted articles: http://nn.neurology.org/content/7/4/e720.full.html\#\#otherarticles

This article, along with others on similar topics, appears in the following collection(s):

All Immunology

http://nn.neurology.org//cgi/collection/all_immunology

Peripheral neuropathy

http://nn.neurology.org//cgi/collection/peripheral_neuropathy

Information about reproducing this article in parts (figures,tables) or in its entirety can be found online at:

http://nn.neurology.org/misc/about.xhtml\#permissions

Information about ordering reprints can be found online:

http://nn.neurology.org/misc/addir.xhtml\#reprintsus

Neurol Neuroimmunol Neuroinflamm is an official journal of the American Academy of Neurology.

Published since April 2014, it is an open-access, online-only, continuous publication journal. Copyright

Copyright $\odot 2020$ The Author(s). Published by Wolters Kluwer Health, Inc. on behalf of the American

Academy of Neurology.. All rights reserved. Online ISSN: 2332-7812.

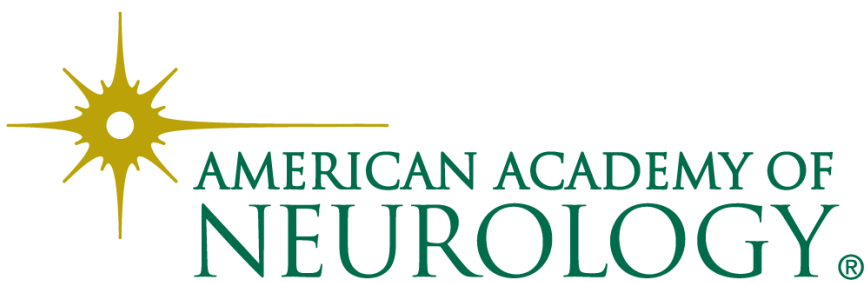

